\title{
Н.И. Хаммадов
}

\section{ПОИСК ГЕНЕТИЧЕСКИХ МАРКЕРОВ ВИРУСА КЛЕЩЕВОГО ЭНЦЕФАЛИТА ДЛЯ ЕГО СПЕЦИФИЧНОЙ ИНДИКАЦИИ}

ФГБНУ «Федеральный иентр токсикологической, радиационной и биологической безопасности», Казань, Российская Федерация

Цель исследования - анализ генетических маркеров вируса клещевого энцефалита, которые можно использовать для специфичной индикации максимально большего числа штаммов и изолятов вируса. Материалы и методы. В качестве амплифицируемого материала использовалась плазмидная ДНК и нуклеиновые кислоты клещей рода Ixodes и Dermacentor. Полимеразную цепную реакцию осуществляли на амплификаторе «С1000» с оптическим блоком «CFX96» (BioRad). Видовое (штаммовое) разнообразие выявляемых с применением анализируемых генетических маркеров организмов определяли в программной утилите «nBLAST». Дизайн нуклеотидных последовательностей праймеров и зондов проводили, используя программу «Vector NTI 9.1.0» (Invitrogen Corporation). Выделение нуклеиновых кислот производили методом магнитной сорбции с комплектом реагентов «МАГНО-сорб». Праймеры и зонды синтезировали в ЗАО «Евроген» (Москва, Россия). Для ПЦР использовались реактивы производства ЗАО «Синтол» (Москва, Россия). Результаты и обсуждение. При индикации генома вируса клещевого энцефалита основным критерием выбора маркерной последовательности является специфичное выявление нуклеиновых кислот только искомого микроорганизма. Для поиска специфичной маркерной нуклеотидной последовательности произведен анализ полногеномных нуклеотидных последовательностей различных штаммов и изолятов вируса клещевого энцефалита. Взаимное сравнение всех указанных выше геномов позволило определить семь условно консервативных локусов, характеризующихся минимальной вариабельностью нуклеотидов. Опираясь в дальнейшей работе на результаты выравнивания нуклеотидных последовательностей изолятов вируса клещевого энцефалита, в том числе учитывая нуклеотидные последовательности гетерогенных микроорганизмов, выполнен дизайн праймеров и зондов для амплификации каждого из маркерных локусов, наиболее аналитически значимые олигонуклеотиды разработаны на основе локусов 4 и 7. Амплификация с олигонуклеотидными затравками для индикации вируса клещевого энцефалита была результативной как в отдельной ПЦР с положительным контролем, так и в сочетании с ДНК клещей.

Ключевые слова: вирус клещевого энцефалита, специфичность, полиморфизм генома, ПЦР, локусы, генетические маркеры, олигонуклеотиды, индикация.

Корреспондирующий автор: Хаммадов Наиль Ильдарович, e-mail: nikhammadov@mail.ru.

Для цитирования: Хаммадов Н.И. Поиск генетических маркеров вируса клещевого энцефалита для его специфичной индикации. Проблемы особо опасных инфрекций. 2020; 2:122-128. DOI: 10.21055/0370-1069-2020-2-122-128

Поступила 21.01.20. Отправлена на доработку 13.02.20. Принята к публ. 03.03.20.

\section{N.I. Khammadov}

\section{Search for Genetic Markers of Tick-Borne Encephalitis Virus for Its Specific Indication, Genomic Analysis}

\author{
Federal Center of Toxicological, Radiation and Biological Safety, Kazan, Russian Federation
}

Abstract. Objective of the study is to analyze the genetic markers of tick-borne encephalitis virus, which can be used to specifically indicate the maximum number of virus strains and isolates. Materials and methods. Plasmid DNA and nucleic acids of the tick, the genus Ixodes and Dermacentor, were used as amplified material. Polymerase chain reaction (PCR) was conducted on C1000 amplifier with a CFX96 optical unit (BioRad). The species (strain) variety of detected organisms, using the analyzed genetic markers, was determined in the nBLAST software utility. The design of the nucleotide sequences of primers and probes was performed using "Vector NTI 9.1.0" (Invitrogen Corporation). Nucleic acids were isolated by magnetic sorption with a reagent panel MAGNO-sorb. Primers and probes were synthesized at "Evrogen" company, Moscow, Russia. The reagents for PCR were manufactured by "Syntol" company, Moscow, Russia. Results and discussion. When indicating the genome of the tick-borne encephalitis virus, the main criterion for choosing a marker sequence is the specific detection of nucleic acids of only the desired microorganism. The genomewide nucleotide sequences of various strains and isolates of tick-borne encephalitis virus were analyzed to search for a specific marker nucleotide sequence. Mutual comparison of all the above mentioned genomes made it possible to determine 7 conventionally conservative loci characterized by minimal nucleotide variability. The further work was based on the results of alignment of the nucleotide sequences of tick-borne encephalitis virus isolates, including the nucleotide sequences of heterogeneous microorganisms; primers and probes were designed to amplify each of the marker loci; the most analytically significant oligonucleotides were developed based on loci 4 and 7. Amplification with oligonucleotide primers to indicate tick-borne encephalitis virus was effective, both in a separate PCR with a positive control, and in combination with tick DNA.

Key words: Tick-borne encephalitis virus, specificity, genome polymorphism, PCR, loci, genetic markers, oligonucleotides, indication.

Conflict of interest: The authors declare no conflict of interest. 
Corresponding author: Nail I. Khammadov, e-mail: nikhammadov@mail.ru.

Citation: Khammadov N.I. Search for Genetic Markers of Tick-Borne Encephalitis Virus for Its Specific Indication, Genomic Analysis. Problemy Osobo Opasnykh Infektsii [Problems of Particularly Dangerous Infections]. 2020; 2:122-128. (In Russian). DOI: 10.21055/0370-1069-2020-2-122-128

Received 21.01.20. Revised 13.02.20. Accepted 03.03.20.

Khammadov N.I., ORCID: http://orcid.org/0000-0001-5669-1486

Нахождение человека в лесопарковой зоне, независимо от близости к населенным пунктам, сопряжено с риском укусов кровососущих насекомых (кроме времени года, характеризующегося отрицательными температурами). Кроме дискомфорта от самого укуса, существует риск инфицирования различными заболеваниями, переносчиками которых являются кровососущие насекомые. Чаще всего переносчиками инфекционных болезней в Приволжском федеральном округе Российской Федерации являются иксодовые клещи; сообщения об инфекционных заболеваниях, вызванных укусом клеща, не редки и в других регионах страны, а также за ее пределами [1-5]. Особо актуальными являются клещевой энцефалит и болезнь Лайма, они чаще всего регистрируются при укусах клещей и могут нанести тяжкий вред здоровью [6-8]. По сравнению с другими инфекциями, поражающими репродуктивную систему, органы пищеварения и дыхания $[9,10]$, клещевой энцефалит характеризуется поражением нервной системы [11]. При схожей симптоматике клещевого энцефалита с бактериальными инфекциями, поражающими центральную нервную систему, их лечение и профилактика существенно отличаются, что подчеркивает необходимость своевременной специфической индикации клещевого энцефалита. Хорошим маркером для индикации клещевого энцефалита являются его нуклеиновые кислоты.

Возбудителем клещевого энцефалита является РНК-содержащий вирус, принадлежащий к семейству Flaviviridae, роду Flavivirus, виду Tick-borne encephalitis virus.

В России за 2009-2013 гг. зафиксировано 333,79 случаев укусов клещей на 10 тыс. населения, при этом в 2,15 случаев (на 10 тыс. населения) присасывание клеща стало причиной заболевания клещевым энцефалитом [12].

Для индикации клещевого энцефалита используют серологические и молекулярно-генетические методы; в представленной работе показан анализ наиболее подходящих генетических маркеров для индикации вируса клещевого энцефалита.

Цель исследования - анализ генетических маркеров вируса клещевого энцефалита, которые можно использовать для специфической индикации максимально большего числа штаммов и изолятов вируса.

\section{Материалы и методы}

Использованная в данной работе методология биоинформационного анализа геномов различных изолятов всех серотипов возбудителей боррелиоза и клещевого энцефалита с последующим дизайном праймеров и зонда имеет общие принципы, которые используются и для других микроорганизмов [13,
14]. Искомые нуклеотидные последовательности определены путем поисковых запросов в базе данных NCBI (Национальный центр биологической информатизации). Видовое (штаммовое) разнообразие выявляемых организмов с применением анализируемых генетических маркеров определяли в программной утилите «nBLAST». Дизайн нуклеотидных последовательностей праймеров и зондов проводили, используя программу «Vector NTI 9.1.0» (Invitrogen Corporation). При дизайне олигонуклеотидных затравок учитывали возможность амплификации целевых ДНК-маркеров (для индикации клещевых инфекций) и ДНК-маркеров внутреннего контроля амплификации (ДНК клеща) в единых условиях амплификации.

В качестве амплифицируемого материала использовалась плазмидная ДНК (положительный контроль, синтезированный в $3 \mathrm{AO}$ «Евроген», Россия) и нуклеиновые кислоты клещей родов Ixodes и Dermacentor. Полимеразную цепную реакцию (ПЦР) осуществляли на амплификаторе «С1000» с оптическим блоком «CFX96» (BioRad). При работе с образцами клещей проводили пробоподготовку, включающую в себя такие этапы, как гомогенезация (образец и ступка с пестиком предварительно охлаждены до $-70{ }^{\circ} \mathrm{C}$ ) и экстракция (физиологическим раствором $\mathrm{NaCl}$ ). Выделение нуклеиновых кислот производили методом магнитной сорбции с комплектом реагентов «МАГНО-сорб», вариант 100-200 («АмплиСенс», ФБУН ЦНИИ Эпидемиологии, Россия), согласно инструкции производителя.

Для ПЦР амплификации использовали следующий состав реакционной смеси из расчета на одну пробу: 1,5 мкл $25 \mathrm{mM}$ раствора $\mathrm{MgCl}_{2} ; 1,5$ мкл 2,5 mM раствора dNTP; 1,5 мкл 10x буфера для ПЦР; по 0,5 мкл 10 pM раствора каждого зонда для ПЦР; по 0,5 мкл $10 \mathrm{pM}$ раствора каждого прямого и обратного праймеров; 0,5 мкл Таq-полимеразы; 5 мкл нуклеиновых кислот и 3,5 деионизированной воды. Праймеры и зонды синтезировали в $3 \mathrm{AO}$ «Евроген» (Москва, Россия). Для ПЦР использовались реактивы производства ЗАО «Синтол» (Москва, Россия). Конечный объем реакционной смеси составил 15 мкл. Реакционная смесь для ОТ-ПЦР (ПЦР с обратной транскрипцией молекулы РНК) отличалась от вышеуказанной смеси наличием фермента MMLV для обратной транскрипции (3АО «Евроген», Москва, Россия) в количестве 0,2 мкл на одну реакцию. Амплификация нуклеиновых кислот осуществлялась по следующей программе: 2 мин;

I стадия - денатурация ДНК при $95{ }^{\circ} \mathrm{C}$ в течение

II стадия - 5 циклов, состоящих из 10 с при $95{ }^{\circ} \mathrm{C}, 30$ с при $57,7{ }^{\circ} \mathrm{C}$;

III стадия - 40 циклов, состоящих из 10 с при 
$95^{\circ} \mathrm{C}, 30$ с при $57,7^{\circ} \mathrm{C}$.

Детекция результата ПЦР (флуоресценция) происходит на каждом из 40 циклов третьей стадии ПЦР при $59{ }^{\circ} \mathrm{C}$ по каналам Fam, Rox, R6G и Cy5. OT-ПЦР осуществляли по схожей программе с добавлением этапа обратной транскрипции $\left(37^{\circ} \mathrm{C}\right.$ в течение 30 мин) до основной программы амплификации.

\section{Результаты и обсуждение}

При индикации генома вируса клещевого энцефалита основным критерием выбора маркерной последовательности является специфичное выявление нуклеиновых кислот только искомого микроорганизма. Кроме искомого вида Tick-borne encephalitis virus (NCBI: txid11084), род Flavivirus насчитывает еще 60 видов вирусов, среди которых есть патогенные для человека вирусы, а именно: вирус денге (NCBI: txid12637), вирус японского энцефалита (NCBI: txid11072), вирус лихорадки Западного Нила (NCBI: txid11082), вирус желтой лихорадки (NCBI: txid11089), вирус Зика (NCBI: txid64320) и др. Для поиска специфичной маркерной нуклеотидной последовательности произведен анализ полногеномных нуклеотидных последовательностей различных штаммов и изолятов вируса клещевого энцефалита. Геном вируса клещевого энцефалита представлен в виде РНК, последовательность которого содержит более 11 тыс. нуклеотидов. Анализ вариабельности нуклеотидных последовательностей различных штаммов и изолятов вируса производился относительно их геномов, которые имели следующие идентификационные номера: АВ062063, АВ062064, AB753012, AY169390, DQ989336, EU816450, EU816451, EU816452, EU816455, FJ997899, GQ228395, HM859894, JF819648, JN003205, JN229223, JQ825144, JQ825145, JQ825146, JQ825147, JQ825148, JQ825150, JQ825152, JQ825153, JQ825157, JQ825158, JQ825159, JQ825160, JQ825161, JQ825163, JX498940, KF880803, KF880805, KF951037, KJ739729, KJ739730, KJ739731, KJ914682, KJ914683, KM019546, KP844726, KP844727, KT001070, KT001071, KT001072, KT001073, KT069219, KU761568, KU761570, KU761571, KU761572, KU761573, KU761575, KU761576 и MF374487. Для удобства дальнейшей интерпретации геномного анализа обозначения позиции в геноме вируса будут производиться относительно генома Tick-borne encephalitis virus strain Primorye-633 (GenBank ID: HM859894).

Взаимное сравнение всех указанных выше геномов позволило определить семь условно консервативных локусов, характеризующихся минимальной вариабельностью нуклеотидов. Первый консервативный локус располагался в позиции с 33 по 215 нуклеотид генома вируса клещевого энцефалита, второй локус - с 1092 по 1229 нуклеотид, третий локус - с 2925 по 3071 нуклеотид, четвертый локус с 3177 по 3398 нуклеотид, пятый локус - с 3372 по 3493 нуклеотид, шестой локус - с 5193 по 5323 ну- клеотид и седьмой локус - с 5784 по 5956 нуклеотид. Нуклеотидные последовательности вышеуказанных локусов представлены на рис. 1.

Последовательность нуклеотидов, выделенная желтым цветом, характеризуется идентичностью во всех анализируемых нуклеотидных последовательностях. Выделение белым цветом указывает на точечную замену анализируемого нуклеотида (менее $50 \%$ совпадение по отношению к общему числу анализируемых нуклеотидных последовательностей), этим же цветом выделен «урацил» (особенность программы). Нуклеотиды, выделенные синим цветом, характеризуются идентичностью в большинстве анализируемых нуклеотидных последовательностей (более $50 \%$ совпадение по отношению к общему числу анализируемых нуклеотидных последовательностей).

В каждом из анализируемых локусов есть не вариабельные участки нуклеотидной последовательности, комплементарно которым можно выполнить дизайн олигонуклеотидных праймеров и зондов для амплификации искомого локуса.

Поисковые запросы по этим локусам в программной утилите nBLAST дали полную характеристику относительно принадлежности искомых нуклеотидных последовательностей к геномам различных живых существ. Так, первый локус характеризовался наличием максимально схожей последовательности у 100 объектов, все они относились к вирусу клещевого энцефалита; исключение из результатов поиска названия «Tick-borne encephalitis virus» позволило выявить 19 объектов вируса клещевого энцефалита (97,27-100\% идентичность, 99-100 \% покрытия), в названии которых нет наименования вируса, и 3 вида гетерогенных организмов вирусной природы. Второй локус характеризовался наличием максимально схожей последовательности у 100 объектов, все они относились к вирусу клещевого энцефалита $(94,93-100 \%$ идентичность, 99-100 \% покрытия), исключение из результатов поиска названия «Tick-borne encephalitis virus» позволило выявить 5 объектов вируса клещевого энцефалита (в виде клонированного вектора), в названии которых нет наименования вируса. Третий локус характеризовался наличием максимально схожей последовательности у 95 объектов, все они относились к вирусу клещевого энцефалита (92,52-100 \% идентичность, 99-100 \% покрытия), исключение из результатов поиска названия «Tick-borne encephalitis virus» позволило выявить 2 объекта, один из которых представлен гетерогенным вирусом. Четвертый локус характеризовался наличием максимально схожей последовательности у 100 объектов, все они относились к вирусу клещевого энцефалита (89,19-100 \% идентичность, 99-100 \% покрытия), исключение из результатов поиска названия «Tick-borne encephalitis virus» позволило выявить 1 объект - клонированный вектор вируса клещевого энцефалита. Пятый локус характеризовался наличием максимально схожей последовательности у 100 объектов, все они относи- 


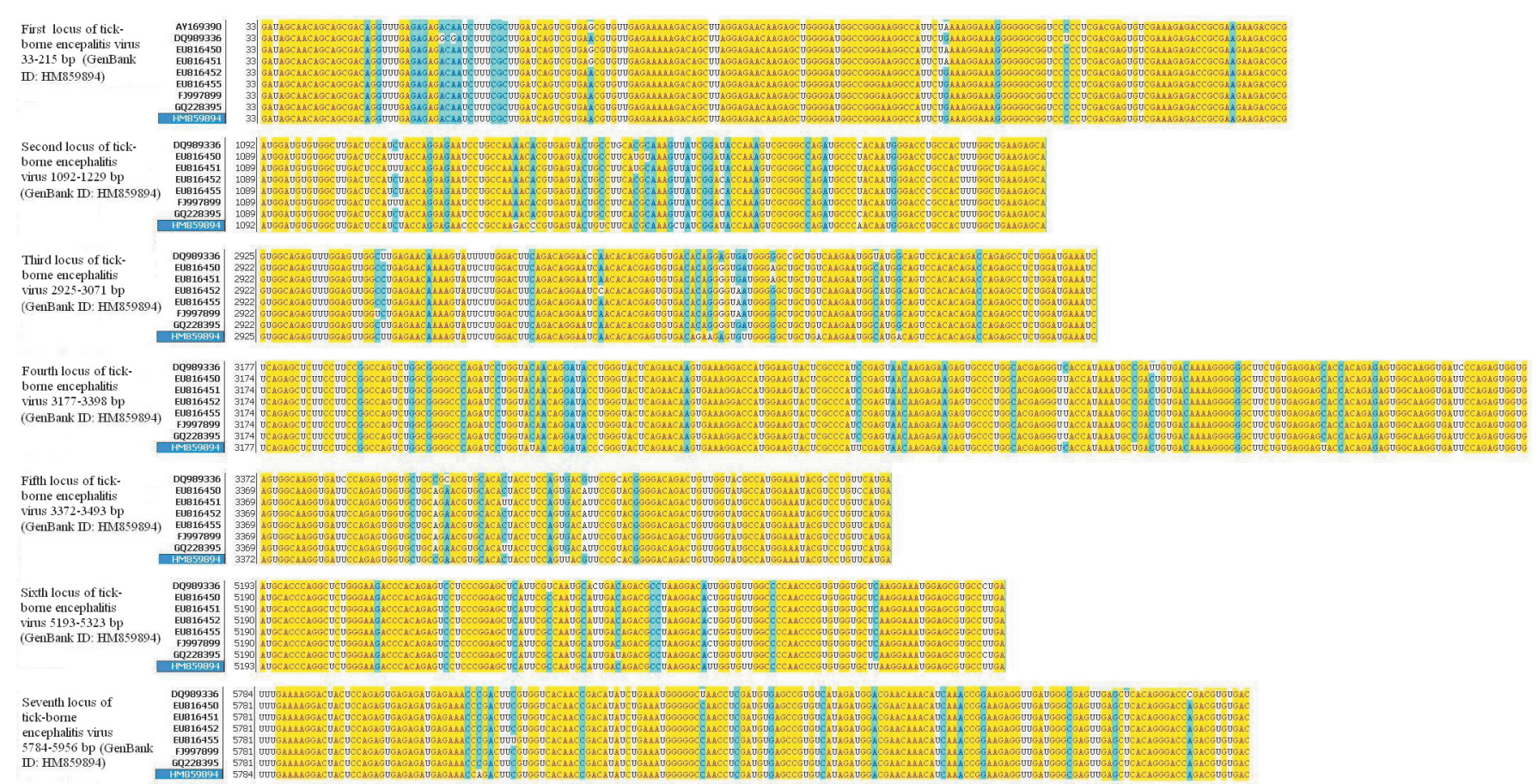

Рис. 1. Сравнение нуклеотидных последовательностей различных изолятов вируса клещевого энцефалита. Единица измерения позиции локуса в геноме указана в парах нуклеотидных оснований (bp)

Fig. 1. Comparison of the nucleotide sequences of various tick-borne encephalitis virus isolates. The unit of measurement of the locus position in the genome is indicated in base pairs (bp)

лись к вирусу клещевого энцефалита $(92,62-100 \%$ идентичность, 97-100 \% покрытия), исключение из результатов поиска названия «Tick-borne encephalitis virus» позволило выявить 1 объект - клонированный вектор вируса клещевого энцефалита. Шестой локус характеризовался наличием максимально схожей последовательности у 100 объектов, все они относились к вирусу клещевого энцефалита (91,6-100 \% идентичность, 99-100 \% покрытия), исключение из результатов поиска названия «Tick-borne encephalitis virus» позволило выявить 1 объект вируса клещевого энцефалита, в названии которого нет наименования вируса, и 3 вида гетерогенных организмов вирусной природы. Седьмой локус характеризовался наличием максимально схожей последовательности у 100 объектов, все они относились к вирусу клещевого энцефалита (90,75-100 \% идентичность, $100 \%$ покрытия), исключение из результатов поиска названия «Tick-borne encephalitis virus» позволило выявить 1 объект - клонированный вектор вируса клещевого энцефалита.

Выделение нуклеотидов желтым, белым или синим цветом осуществлялось по алгоритму, схожему с описаниями рис. 1.

В локусах, представленных на рис. 2, дополнительно к нуклеотидным последовательностям изолятов вируса клещевого энцефалита добавлены нуклеотидные последовательности гетерогенных микроорганизмов, которые в результате анализа в ресурсе «BLAST» характеризовались схожестью нуклеотидной последовательности (первые семь позиций, а именно JF416964, MG720088, NC_027709, DQ462443, DQ235153, DQ235152 и MN537791).
В результате сравнения анализируемых нуклеотидных последовательностей установлено, что при добавлении в сравниваемый список гетерогенных микроорганизмов ранее консервативные нуклеотидные последовательности (потенциальные места для дизайна праймеров и зондов) приобрели значительную вариабельность. Такое изменение сравнительных характеристик анализируемых нуклеотидных последовательностей позволяет сделать вывод о минимальном влиянии выявленных гетерогенных микроорганизмов на специфичность создаваемых олигонуклеотидных затравок при дизайне праймеров и зондов для ПЦР, амплифицирующих применяемые в данной работе маркерные локусы вируса клещевого энцефалита.

Опираясь в дальнейшей работе на результаты выравнивания нуклеотидных последовательностей изолятов вируса клещевого энцефалита, в том числе учитывая нуклеотидные последовательности гетерогенных микроорганизмов, выполнен дизайн праймеров и зондов для амплификации каждого из маркерных локусов (при наличии такой возможности). Для амплификации первого анализируемого локуса и флуоресцентного контроля ПЦР разработаны следующие праймеры и зонд: enceph F locus 1 (gcggtctctttcgacactcgtc), enceph R locus 1 (cggatagcaacagcagcgaca), enceph P locus 1 (c tcttgttctcctaagctgtcttattctcaacacg); все нуклеотидные последовательности имеют направление молекулы 5' $\rightarrow$ 3'. Для амплификации второго анализируемого локуса и флуоресцентного контроля ПЦР разработаны следующие праймеры и зонд: enceph F locus 2 (ctcttcagccaaagtggcaggt), enceph 


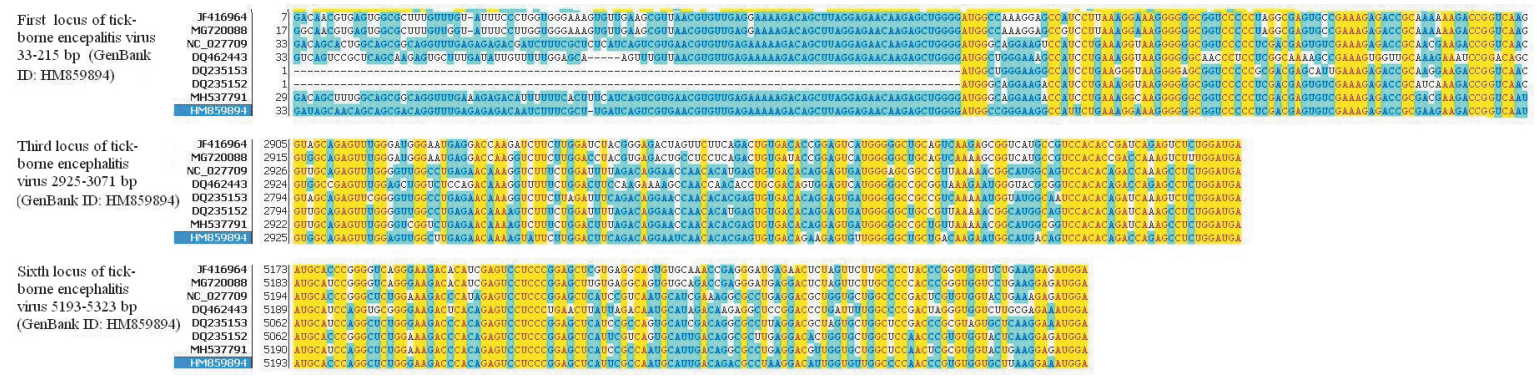

Рис. 2. Сравнение нуклеотидных последовательностей различных изолятов вируса клещевого энцефалита с гетерогенными микроорганизмами. Единица измерения позиции локуса в геноме указана в парах нуклеотидных оснований (bp)

Fig. 2. Comparison of the nucleotide sequences of various tick-borne encephalitis virus isolates with heterogeneous microorganisms. The unit of measurement of the locus position in the genome is indicated in base pairs (bp)

$\mathrm{R}$ locus 2 (atggatgtgtggcttgactccat), enceph $\mathrm{P}$ locus 2 (attgttgggcatctggcegcgac). Для амплификации третьего анализируемого локуса и флуоресцентного контроля ПЦР не получилось разработать праймеры и зонд, так как не удалось найти достаточно консервативные нуклеотидные последовательности в области маркерного локуса, а длины имеющихся консервативных участков недостаточно для достижения необходимого показателя температуры плавления олигонуклеотидов. Для амплификации четвертого анализируемого локуса и флуоресцентного контроля ПЦР разработаны следующие праймеры и зонд: enceph F locus 4 (gctcttcettccggccagtc), enceph $\mathrm{R}$ locus 4 (ccactctggaatcaccttgcca), enceph $\mathrm{P}$ locus 4 (tgaaaggaccatggaagtactcgccc). Для амплификации пятого и шестого анализируемых локусов и флуоресцентных контролейПЦР разработать праймеры и зонды не удалось, так как не обнаружены нуклеотидные последовательности, соответствующие необходимым характеристикам [14]. Для амплификации седьмого анализируемого локуса и флуоресцентного контроля ПЦР разработаны следующие праймеры и зонд: enceph F locus 7 (aggactactccagagtgagagatgagaaa), enceph $\mathrm{R}$ locus 7 (tcaactcgeccatcaacctctt), enceph P locus 7 (tggtcacaaccgacatatctgaaatggg).

В результате дизайна олигонуклеотидных затравок для индикации вируса клещевого энцефалита разработано четыре группы праймеров и зондов для
ПЦР (локусы 1, 2, 4 и 7). Характеристика разработанных олигонуклеотидов относительно количества вариабельных нуклеотидов, количества димеров, количества вторичных структур и температуры плавления представлена в табл. 1 .

Дизайн олигонуклеотидов осуществлялся с учетом минимизации возможной вариабельности нуклеотидных последовательностей искомых изолятов вируса клещевого энцефалита. Во всех случаях, кроме ПЦР-зонда на второй локус, удалось достичь показателя, равного не более одной замене в одном олигонуклеотиде. Все димеры и вторичные структуры характеризовались минимальной длиной (не более четырех нуклеотидов), данный показатель указывает на отсутствие негативного влияния на процесс амплификации.

Для уточнения аналитической значимости каждого из анализируемых локусов генома вируса клещевого энцефалита все разработанные олигонуклеотиды подвергли BLAST-анализу, результаты которого представлены в табл. 2.

Исходя из анализа данных табл. 1 и 2 , установлено, что наиболее аналитически значимые олигонуклеотиды разработаны на основе локусов 4 и 7.

Для контроля амплификации применялись олигонуклеотиды, комплементарные большой субъединице рибосомальной РНК клеща рода Dermacentor reticulatus (GenBank ID: MK880193) и гену цитохро-

Характеристики нуклеотидных последовательностей праймеров и зондов для ПЦР

Characteristics of the nucleotide sequences of primers and probes for PCR

\begin{tabular}{|c|c|c|c|c|c|c|c|c|c|c|c|c|}
\hline $\begin{array}{c}\text { Показатель характеристики / } \\
\text { название олигонуклеотида } \\
\begin{array}{c}\text { Characteristic value / name } \\
\text { of the oligonucleotide }\end{array}\end{array}$ & $\begin{array}{c}\text { Enceph F } \\
\text { locus } 1\end{array}$ & $\begin{array}{c}\text { Enceph R } \\
\text { locus } 1\end{array}$ & $\begin{array}{c}\text { Enceph P } \\
\text { locus } 1\end{array}$ & $\begin{array}{c}\text { Enceph F } \\
\text { locus } 2\end{array}$ & $\begin{array}{c}\text { Enceph R } \\
\text { locus } 2\end{array}$ & $\mid \begin{array}{c}\text { Enceph P } \\
\text { locus 2 }\end{array}$ & $\begin{array}{c}\text { Enceph F } \\
\text { locus } 4\end{array}$ & $\begin{array}{c}\text { Enceph R } \\
\text { locus } 4\end{array}$ & $\begin{array}{c}\text { Enceph P } \\
\text { locus } 4\end{array}$ & $\begin{array}{c}\text { Enceph F } \\
\text { locus } 7\end{array}$ & $\left|\begin{array}{c}\text { Enceph R } \\
\text { locus } 7\end{array}\right|$ & $\begin{array}{c}\text { Enceph P } \\
\text { locus } 7\end{array}$ \\
\hline $\begin{array}{l}\text { Количество вариабельных } \\
\text { нуклеотидов } \\
\text { The number of variable } \\
\text { nucleotides }\end{array}$ & 1 & 1 & 0 & 1 & 0 & 3 & 1 & 0 & 0 & 0 & 1 & 1 \\
\hline $\begin{array}{l}\text { Количество димеров } \\
\text { Number of Dimers }\end{array}$ & 7 & 0 & 11 & 4 & 6 & 4 & 2 & 4 & 2 & 12 & 0 & 9 \\
\hline \begin{tabular}{|l|} 
Количество вторичных \\
структур \\
Number of Hairpin Loops \\
\end{tabular} & 3 & 0 & 5 & 2 & 3 & 1 & 0 & 2 & 0 & 5 & 0 & 4 \\
\hline $\begin{array}{l}\text { Температура плавления, }{ }^{\circ} \mathrm{C} \\
\text { Melting point, }{ }^{\circ} \mathrm{C}\end{array}$ & 57,6 & 58,6 & 64,3 & 57,2 & 57,0 & 67,4 & 57,5 & 58,5 & 64,0 & 57,6 & 57,4 & 64,3 \\
\hline
\end{tabular}


Принадлежности анализируемых нуклеотидных последовательностей к геномам различных живых существ Appurtenance of the analyzed nucleotide sequences to the genomes of various living beings

\begin{tabular}{|c|c|c|c|c|c|c|c|c|c|c|c|c|}
\hline $\begin{array}{c}\text { Показатель } \\
\text { специфичности } \\
\text { Specificity indicator }\end{array}$ & $\begin{array}{l}\text { Enceph F } \\
\text { locus } 1\end{array}$ & $\mid \begin{array}{c}\text { Enceph R } \\
\text { locus } 1\end{array}$ & $\begin{array}{c}\text { Enceph P } \\
\text { locus } 1\end{array}$ & $\begin{array}{c}\text { Enceph F } \\
\text { locus } 2\end{array}$ & $\mid \begin{array}{c}\text { Enceph R } \\
\text { locus } 2\end{array}$ & $\begin{array}{c}\text { Enceph P } \\
\text { locus } 2\end{array}$ & $\begin{array}{c}\text { Enceph F } \\
\text { locus } 4\end{array}$ & $\begin{array}{c}\text { Enceph R } \\
\text { locus } 4\end{array}$ & $\begin{array}{c}\text { Enceph P } \\
\text { locus } 4\end{array}$ & $\begin{array}{c}\text { Enceph F } \\
\text { locus } 7\end{array}$ & $\begin{array}{c}\text { Enceph R } \\
\text { locus } 7\end{array}$ & $\begin{array}{c}\text { Enceph P } \\
\text { locus } 7\end{array}$ \\
\hline $\begin{array}{l}\text { Количество выявляемых } \\
\text { изолятов искомого вируса } \\
\text { The number of detected virus } \\
\text { isolates }\end{array}$ & $>100$ & $>100$ & $>100$ & 99 & $>100$ & $>100$ & $>100$ & $>100$ & 96 & $>100$ & $>100$ & 100 \\
\hline $\begin{array}{l}\text { Количество выявляемых } \\
\text { гетерогенных организмов } \\
\text { The number of detected } \\
\text { heterogeneous organisms }\end{array}$ & 15 & 1 & 7 & 1 & 20 & 2 & 1 & 3 & 0 & 0 & 3 & 3 \\
\hline
\end{tabular}

ма В клеща Ixodes ricinus (GenBank ID: MH336087). Внутренний контроль амплификации разработан для проверки качества выделения нуклеиновых кислот, для ПЦР в этом случае использовали следующие олигонуклеотиды: F Ixodes (catattgaattt gaggaggattttcagt), $\mathrm{R}$ Ixodes (tgtgaagtaagggtggaaagg gat), P Ixodes (Cy5-acactcactcgattttttctttacattttatttta ccttt-RRQ2), F Dermacentor (gctaagagaatggaatttcag ggaa), R Dermacentor (agatgccccaactaagaattcctaat), P Dermacentor (Cy5-aagaaacaattatataaattaaggacaagaag accctaagaa-RRQ2), все нуклеотидные последовательности имеют направление молекулы 5' $\rightarrow$ 3'.

Разработанные праймеры для индикации вируса клещевого энцефалита имеют температуру плавления $(57,75 \pm 0,44)^{\circ} \mathrm{C}$, а праймеры для контроля амплификации - $(56,35 \pm 0,29)^{\circ} \mathrm{C}$, такая разница температур создает более благоприятные условия амплификации праймеров для индикации вируса клещевого энцефалита (при температуре отжига $57,7^{\circ} \mathrm{C}$ ).

Для контроля результата амплификации создан положительный контроль со специфической вставкой маркерных последовательностей вируса клещевого энцефалита (5'gctcttccttccggccagtcaggactact ccagagtgagagatgagaaatgaaaggaccatggaagtactcgccctggt cacaaccgacatatctgaaatgggtggcaaggtgattccagagtggaaga ggttgatgggcgagttga3'). Вставку маркерной последовательности в плазмиду «pAL2-T» заказали в $3 \mathrm{AO}$ «Евроген». Результат амплификации разработанных олигонуклеотидных затравок с нуклеиновыми кислотами клещей и плазмидного контроля изображен на рис. 3.

Амплификация с олигонуклеотидными затравками для индикации вируса клещевого энцефалита была результативной как в отдельной ПЦР с положительным плазмидным контролем, так и в сочетании с ДНК клещей.

Для определения предела обнаружения вируса подготовили 12 десятикратных разведений плазмидной ДНК $\mathrm{c}$ начальной концентрацией 426,6 нг/мкл, что соответствует (для применяемой плазмиды) 125663628880 молекул в микролитре раствора. Каждое из 12 разведений ДНК амплифицировали в восьми повторах, начальное разведение для амплификации составило $10^{-3}$. Предельное работоспособное (шесть случаев амплификации из 8 реакций) разведение плазмидной ДНК составило $10^{-11}$, что соответствует 6,29 молекул ДНК в реакционной смеси.

Индикация амплификации с олигонуклеотидными затравками для выявления вируса клещевого энцефалита осуществлялась по каналу Rox, a внутреннего контроля амплификации - по каналу Су5.

Применение разработанных олигонуклеотидов позволит с высокой степенью достоверности определять носительство иксодовыми клещами вируса клещевого энцефалита. При этом достоверность эффек-
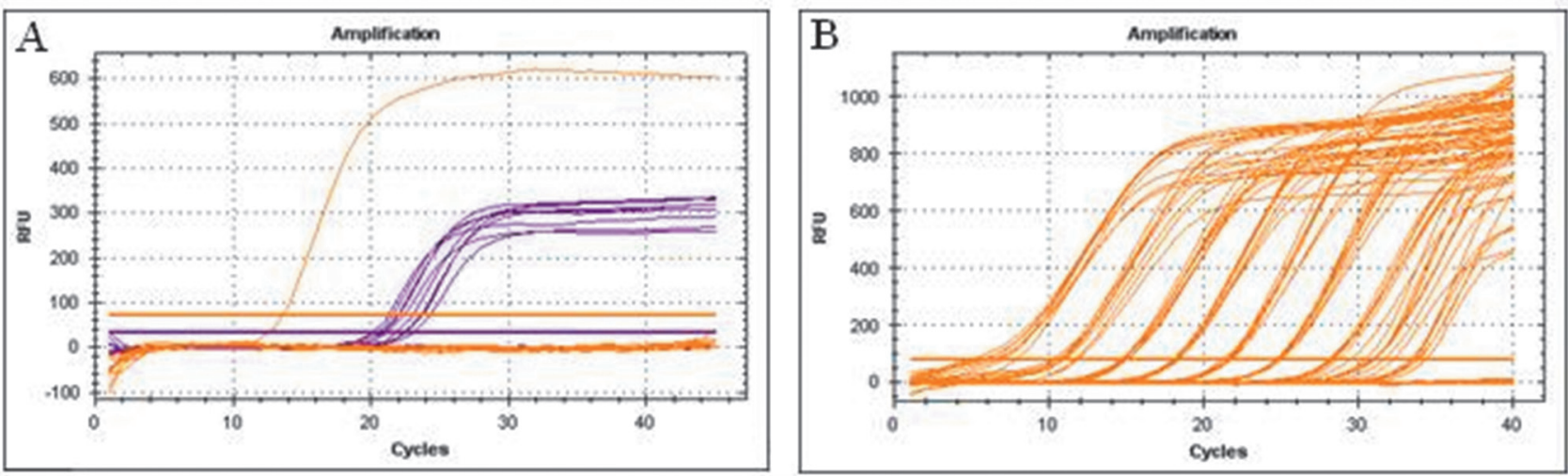

Рис. 3. Амплификация маркерных локусов для индикации вируса клещевого энцефалита:

$\boldsymbol{A}$ - амплификация плазмидного контроля и ДНК клещей; $\boldsymbol{B}$ - амплификация плазмидного контроля для определения предела чувствительности ПЦР

Fig. 3. Amplification of marker loci to indicate tick-borne encephalitis virus:

$\boldsymbol{A}$ - amplification of plasmid control and tick DNA; $\boldsymbol{B}$ - amplification of the plasmid control to determine the sensitivity threshold of PCR 
тивности выделения нуклеиновых кислот будет подтверждаться амплификацией внутреннего контроля (амплификация геномной ДНК клеща), а достоверность выявления РНК вируса клещевого энцефалита будет достигаться при амплификации (ОТПЦР) обоих выбранных в данной работе локусов (№ 4 и 7).

Конфликт интересов. Авторы подтверждают отсутствие конфликта финансовых/нефинансовых интересов, связанных с написанием статьи.

\section{Список литературы}

1. Туник Т.В., Ляпунов А.В., Хаснатинов М.А., Данчинова Г.А., Арбатская Е.В., Чапоргина Е.А., Каверзина А.С., Петрова И.В., Савелькаева М.В., Горбунова Е.Л. Эффективность антибиотикопрофилактики болезни Лайма (клещевого боррелиоза) у лиц, пострадавших от укусов иксодовых клещей. Acta Biomedica Scientifica. 2012; (2-1):67-70.

2. Madison-Antenucci S., Kramer L.D., Gebhardt L.L., Kauffman E. Emerging tick-borne diseases. Clin. Microbiol. Rev. 2020; 33(2):e00083-18. DOI: 10.1128/CMR.00083-18.

3. Ляпунов А.В., Данчинова Г.А., Хаснатинов М.А., Туник Т.В., Арбатская Е.В., Петрова И.В., Савелькаева М.В., Горбунова Е.Л., Гладкова Е.П. Встречаемость антигена вируса клещевого энцефалита у населения, пострадавшего от укусов иксодовых клещей. Бюллетень Восточно-Сибирского научного центра Сибирского отделения Российской академии медиинских наук. 2013; (2-2):115-8.

4. Оглезнева Е.Е., Ильина Т.М., Чеботарева Т.Я. Ситуация по заболеваемости инфекциями, передающимися при укусах клещей, и мерах их профилактики на территории Белгородской области за период 2015-8 месяцев 2017 гг. Инфекиия и иммунитет. 2017; S:476.

5. Данчинова Г.А., Ляпунов А.В., Манзарова Э.Л., Ляпунова Н.А., Соловаров И.С., Петрова И.В., Хаснатинов М.А.' Необходимость совершенствования экстренной диагностики клещевых инфекций у людей, пострадавших от укусов иксодовых клещей за пределами России. Acta Biomedica Scientifica. 2018; 3(4):129-37. DOI: 10.29413/ABS.2018-3.4.19.

6. Конев В.П. Клещевой энцефалит: патоморфология и молекулярная патология. Дальневосточный журнал инфекиионной патологии. 2007; 11:87-90.

7. Пиневич О.С., Попонникова Т.В., Вахрамеева Т.Н., Бедарева Т.Ю., Галиева Г.Ю., Берданова В.С. Клинические и этиологические аспекты клещевых микст-инфекций у детей. Мать и дитя в Кузбассе. 2008; 3:30-5.

8. Леонова Г.Н., Крылова Н.В., Павленко Е.В., Беликов С.И., Кондратьев И.Г. Значение дальневосточных штаммов вируса клещевого энцефалита в инфекционной патологии. Здоровье населения и среда обитания. 2012; 1:4-6.

9. Хусаинов Ф.М., Евстифеев В.В., Хусаинова Г.И., Хамидуллина Р.З., Фазулзянов И.Р., Яковлев С.И. Клиникоэпизоотологическое проявление хламидийного аборта у коз. Ветеринарный врач. 2018; 3:41-4.

10. Гумеров В.Г., Евстифеев В.В., Макаев Х.Н., Галиуллин А.К., Каримуллина И.Г., Коннов М.Н. Эпизоотологический и серологический мониторинг смешанных респираторнокишечных инфекций крупного рогатого скота. Ученые записки Казанской государственной академии ветеринарной медииинь им. Н.Э. Баумана. 2019; 237(1):56-60. DOI: 10.31588/2413-42011883-237-1-56-60

11. Этенко Д.А., Громова О.А., Субботин А.В., Семенов В.А. Комплексная терапия очаговой формы смешанной клещевой энцефалит-боррелиозной инфекции. Неврология, нейропсихиатрия, психосоматика. 2016; 8(3):26-30. DOI: 10.14412/2074хиатрия, психосомат

12. Носков А.К., Ильин В.П., Андаев Е.И., Пакскина Н.Д., Веригина Е.В., Балахонов С.В. Заболеваемость клещевым вирусным энцефалитом в российской федерации и по федеральным округам в 2009-2013 гг., эпидемиологическая ситуация в 2014 г. и прогноз на 2015 г. Проблемы особо опасных инфекиий. 2015; 1:46-50. DOI: 10.21055/0370-1069-2015-1-46-50.

13. Khammadov N.I., Aleksandrova N.M., Khammadova A.V., Shuralev E.A. Evaluation of the Effectiveness of Genetic Markers of Mycobacteria for Assessing the Disinfection Quality by Viability Real Time PCR. BioNanoScience. 2019; 9:918-27. DOI: 10.1007। s12668-019-00654-8.

14. Khammadova A.V., Shuralev E.A., Khammadov N.I., Oumarou B.M., Faizov T.K., Mukminov M.N. Design of primers for identification of honey bee viruses in multiplex-PCR. Astra Salvensis. 2017; 2017:481-90.

\section{References}

1. Tunik T.V., Lyapunov A.V., Khasnatinov M.A., Danchinova G.A., Arbatskaya E.V., Chaporgina E.A., Kaverzina A.S., Petrova I.V., Savel'kaeva M.V., Gorbunova E.L. [The effectiveness of antibiotic prophylaxis of Lyme disease (tick-borne borreliosis) in individuals affected by bites of ixodid ticks]. Acta Biomedica Scientifica. 2012; (2-1):67-70.

2. Madison-Äntenucci S., Kramer L.D., Gebhardt L.L., Kauffman E. Emerging tick-borne diseases. Clin. Microbiol. Rev. 2020; 33(2):e0083-18. DOI: 10.1128/CMR.00083-18.

3. Lyapunov A.V., Danchinova G.A., Khasnatinov M.A., Tunik T.V., Arbatskaya E.V., Petrova I.V., Savelkaeva M.V., Gorbunova E.L., Gladkova E.P. [The incidence of tick-borne encephalitis virus antigen in a population affected by tick bites]. Byulleten' VostochnoSibirskogo nauchnogo tsentra Sibirskogo otdeleniya Rossijskoj akademii meditsinskih nauk. [Bulletin of the East Siberian Scientific Center of the Siberian Branch of the Russian Academy of Medical Sciences]. 2013; (2-2):115-8.

4. Oglezneva E.E., Ilina T.M., Chebotareva T.YA. [The situation with the incidence of infections transmitted by tick bites and measures for their prevention in the territory of the Belgorod region for the period $2015-8$ months of 2017]. Infekciva $i$ immunitet. [Russian journal of Infection and immunity]. 2017; S:476.

5. Danchinova G.A., Lyapunov A.V., Manzarova E.L., Lyapunova N.A., Solovarov I.S., Petrova I.V., Khasnatinov M.A. [The need to improve emergency diagnosis of tick-borne infections in people affected by bites of Ixodidae ticks outside of Russia]. Acta Biomedica Scientifica. 2018; 4:129-37. DOI: 10.29413/ABS.20183.4.19.

6. Konev V.P. [Tick-borne encephalitis: pathomorphology and molecular pathology]. Dal'nevostochnyj zhurnal infektsionnoj patologii. [Far Eastern Journal of Infectious Pathology]. 2007; 11:87-90.

7. Pinevich O.S., Poponnikova T.V., Vahrameeva T.N., Bedareva T.Y., Galieva G.Y., Berdanova V.S. Clinical and etiological aspects of tick-borne mixed infections in children]. Mat' $i$ ditya $y$ Kuzbasse. [Mother and child in Kuzbass]. 2008; 3:30-5.

8. Leonova G.N., Krylova N.V., Pavlenko E.V., Belikov S.I., Kondrat'ev I.G. [The importance of Far Eastern tick-borne encephalitis virus strains in infectious pathology]. Zdorov'e naseleniya i sreda obitaniya. [Public Health and Life Environment]. 2012; 1:4-6.

9. Khusainov F.M., Evstifeev V.V., Khusainova G.I., Khamidullina R.Z., Fazulzyanov I.R., Yakovlev S.I. [Clinical and epizootiological manifestation of chlamydial abortion in goats]. Veterinarnyj vrach [Veterinarian]. 2018; 3:41-4.

10. Gumerov V.G., Evstifeev V.V., Makaev H.N., Galiullin A.K., Karimullina I.G., Konnov M.N. [Epizootiological and serological monitoring of mixed respiratory and intestinal infections in cattle]. Uchenye zapiski Kazanskoj gosudarstvennoj akademii veterinarnoj meditsiny im. N.E. Baumana. [Scientific notes of Kazan State Academy of Veterinary Medicine named after N.E. Bauman]. 2019; 1:56-60. DOI: 10.31588/2413-4201-1883-237-1-56-60

11. Etenko D.A., Gromova O.A., Subbotin A.V., Semenov V.A. [Combined therapy of the focal form of mixed tick-borne encephalitis-borreliosis infection]. Nevrologiya, nejropsikhiatriya, psihosomatika [Neurology, neuropsychiatry, psychosomatics]. 2016; 3:26-30. DOI: $10.14412 / 2074-2711-2016-3-26-30$.

12. Noskov A.K., Ilin V.P., Andaev E.I., Pakskina N.D., Verigina E.V., Balahonov S.V. FTick-borne viral encephalitis incidence in the Russian Federation and federal districts in 2009-2013, epidemiological situation in 2014 and forecast for 2015]. Problemy Osobo Opasnykh Infektsii [Problems of Particularly Dangerous Infections].. 2015; (1):46-50. DOI: 10.21055/0370-1069-2015-1-46-50.

13. Khammadov N.I., Aleksandrova N.M., Khammadova A.V., Shuralev E.A. Evaluation of the Effectiveness of Genetic Markers of Mycobacteria for Assessing the Disinfection Quality by Viability Real Time PCR. BioNanoScience. 2019; 9:918-27. DOI: 10.1007/ s12668-019-00654-8.

14. Khammadova A.V., Shuralev E.A., Khammadov N.I., Oumarou B.M., Faizov T.K., Mukminov M.N. Design of primers for identification of honey bee viruses in multiplex-PCR. Astra Salvensis. 2017; 2017:481-90.

\section{Authors:}

Khammadov N.I. Federal Center of Toxicological, Radiation and Biological Safety, Kazan, Russian Federation. Nauchniy Gorodok-2, Kazan, Tatarstan, 420075, Russian Federation. E-mail: vnivi@mail.ru.

\section{Об авторах:}

Хаммадов Н.И. Федеральный центр токсикологической, радиационной и биологической безопасности. Российская Федерация, 420075, Татарстан, Казань, Научный городок-2. E-mail: vnivi@mail.ru. 